\title{
Strategi Pemberdayaan Ekonomi Mustahiq Melalui Pendistribusian Zakat Produktif
}

\author{
Aliman Syahuri Zein \\ Email: alimansya@iainpadangsidimpuan.ac.id \\ Institut Agama Islam Negeri Padangsidimpuan \\ Jl. H.T. Rizal Nurdin KM.4,5 Sihitang Padangsidimpuan
}

\begin{abstract}
Zakat is an instrument of fiscal policy that is very strategic to develop a society's economy. This is supported by the majority of Indonesian Muslims who are estimated to be able to pay zakat. The potential for zakat in Indonesia is reaching 6.5 trillion per year. This potential should be able to reduce poverty if it can be managed properly. The concept of mustahiq economic empowerment carried out by the Mandailing Natal District Baznas is limited to controlling the business, Controlling is done indirectly. Constraints faced by Baznas Mandailing Natal in mustahiq economic empowerment include; Baznas officers are limited, mustahiq lives far away, making it difficult to reach, mustahiq misuse the zakat funds received, so it is not in accordance with the proposed. The right strategy carried out by Baznas Mandailing Natal for future economic empowerment mustahiq, among others: a) change the pattern of productive zakat distribution from traditional to more modern, b) apply the $5 \mathrm{C}$ principle to assess the character of the mustahiq candidates, c) make maximum assistance to the business mustahiq.
\end{abstract}

\section{Keywords: Strategic, Economic Empowerment, Zakah, Productive}

\begin{abstract}
Abstrak
Zakat merupakan instrumen kebijakan fiskal yang sangat strategis untuk pembangunan ekonomi masyarakat. Hal ini didukung oleh jumlah mayoritas ummat Islam Indonesia yang diperkirakan mampu membayar zakat, namun belum menunaikannya karena berbagai alasan. Potensi zakat di Indonesia cukup tinggi, mencapai 6,5 trilyun per tahun. Potensi ini seharusnya mampu mengurangi angka kemiskinan jika dapat dikelola dengan tepat. Konsep pengelolan zakat produktif yang dilakukan Baznas Kabupaten Mandailing Natal masih tergolong tradisional. Artinya baru hanya melibatkan pihak Baznas dan mustahiq. Konsep pemberdayaan ekonomi mustahiq yang dilakukan Baznas Kabupaten Mandailing Natal hanya sebatas controlling usaha. Controlling ini dilakukan secara tidak langsung, biasanya melalui telepon. Kegiatan controlling ini dilakukan dengan tidak terjadwal. Kendala yang dihadapi Baznas Mandailing Natal dalam pemberdayaan ekonomi mustahiq antara lain; SDM (petugas) Baznas yang terbatas, tempat tinggal mustahiq jauh, mustahiq menyalahgunakan dana zakat yang diterima, Strategi yang tepat dilakukan oleh Baznas Mandailing Natal untuk pemberdayaan ekonomi mustahiq ke depan, antara lain: a) merubah pola distribusi zakat produktif dari tradisional menjadi lebih modern, b)menerapkan prinsip $5 \mathrm{C}$ untuk menilai karakter calon mustahiq, c)melakukan pendampingan secara maksimal terhadap usaha mustahiq.
\end{abstract}

Kata Kunci: Strategi, Pemberdayaan Ekonomi, Zakat, Produktif 


\section{Strategi Pemberdayaan Ekonomi Mustahiq Melalui \\ Pendistribusian Zakat Produktif}

Aliman Syahuri Zein

\section{Pendahuluan}

Zakat merupakan salah satu instrumen kebijakan fiskal yang sangat strategis dalam upaya pembangunan ekonomi suatu masyarakat melalui pengentasan kemiskinan. Hal ini didukung oleh jumlah mayoritas ummat Islam Indonesia yang diperkirakan mampu membayar zakat, namun belum menunaikannya karena berbagai alasan. Padahal potensi zakat di Indonesia cukup tinggi, mencapai 6,5 trilyun per tahun. Potensi ini seharusnya mampu mengurangi angka kemiskinan jika dapat dikelola dengan tepat. Secara teori, zakat dapat dikaji dalam dua dimensi, yaitu dimensi ibadah dan dimensi sosial. Dalam dimensi ibadah zakat merupakan cerminan dari keimanan seorang muslim, karena merupakan perintah Allah Swt. Sedangkan dalam dimensi sosial zakat merupakan piranti keuangan yang dapat mewujudkan keadilan distribusi pendapatan, sehingga diharapkan mampu mewujudkan kesejahteraan dalam masyarakat. Oleh karena itu, zakat perlu dikelola dengan tepat, agar memberikan manfaat sesuai yang diharapakan. Namun untuk pengelolaan tersebut perlu melibatkan berbagai unsur, misalnya mustahiq selaku masyarakat penerima zakat, muzakki sebagai pihak yang akan mampu menunaikan zakat, dan amil zakat atau pemerintah (dalam hal ini BAZ dan LAZ).

Mampu atau tidaknya zakat untuk memberdayakan ekonomi masyarakat sangat tergantung pada berbagai hal, diantaranya sistem distribusi yang diterapkan. Distribusi zakat dapat digolongkan pada dua hal, yaitu; distribusi secara konsumtif dan distribusi secara produktif. Secara konsumtif berarti harta zakat langsung dibagikan kepada mustahiq untuk digunakan secara konsumtif. Sementara jika secara produktif, maka mustahiq tidak dapat secara langsung mengkonsumsi harta zakat tersebut, melainkan harus diproduktifkan terlebih dahulu, sehingga yang akan dikonsumsi kelak adalah hasil dari harta yang diproduktifkan. Maka untuk menciptakan hal ini, perlu peran pemerintah. Dimana pemerintah berkewajiban memberikan perlindungan, pembinaan dan pelayanan kepada muzakki, mustahiq dan amil zakat untuk meningkatkan kesadaran membayar zakat, meningkatkan kesejahteraan umat dan keadilan sosial serta meningkatkan nilai guna dari pemberian zakat sebagaimana yang 
diamanhkan oleh Undang-Undang No. 38 tahun 1999 tentang pengelolaan Zakat.

Kabupaten Mandailing Natal, merupakan salah satu kabupaten di provinsi Sumatera Utara yang merupakan daerah strategis dalam pengembangan sosial ekonomi dan sosial keagamaan dalam upaya memberdayakan ekonomi masyarakat. Data Badan Pusat statistik Kabupaten Mandailing Natal menunjukkan jumlah penduduk Mandailing Natal tahun 2017 sebanyak 439505 jiwa. Semenatara itu, Jumlah penduduk miskin di kabupaten ini masih tergolong tinggi. Pada tahun 2017, jumlah penduduk miskin berjumlah 50.900 jiwa atau sekitar $12 \%$ dari total penduduk. Mayoritas penduduk beragama Islam. Untuk itu, zakat merupakan salah satu solusi bagi upaya pemberdayaan ekonomi masyarakat, melalui maksimalisasi potensi zakat. Data dari BAZNAS kabuapten Mandailing Natal menyebutkan, Pada tahun 2017, jumlah dana zakat yang telah tersalurkan baru sebanyak 2,5 milyar. Sedangkan menurut asumsi peneliti jika zakat dioptimalkan maka dapat diperkirakan potensinya mencapai sekitar 35 milyar per tahun. Dengan rincian zakat yang bersumber dari masyarakat, berkisar 50\% dari 94.948 keluarga yang merupakan golongan wajib zakat dengan rata-rata besarnya zakat Rp. 50.000 per bulan. Selanjutnya potensi zakat dari lingkungan pemerintah Kabupaten Mandailing Natal, misalkan saja PNS berjumlah 7.562 mengeluarkan rata-rata Rp 25.000 setiap bulannya, maka dalam satu tahun jumlahnya mencapai Rp. 2 milyar, sehingga total dari penggalian potensi zakat setiap tahun mencapai 30 milyar. Belum lagi penggalian potensi zakat, infaq dan sedekah perusahaanperusahaan swasta yang berinvestasi di Mandailing Natal, sehingga potensi zakat diprediksi mencapai 35 milyar. Namun kenyataannya zakat belum memberi peran yang siknifikan dalam pemberdayaan ekonomi umat. Hal ini disebabkan banyak hal, salah satu diantaranya stratrgi yang belum tepat dilakukan untuk memberdayakan para mustahiq, sehingga mereka mayoritas hanya menggunakan dana zakat untuk hal produktif saja. Sehingga tidak memberi efek apapun untuk perekonomian mereka khususnya dimasa mendatang. 


\section{Strategi Pemberdayaan Ekonomi Mustahiq Melalui \\ Pendistribusian Zakat Produktif}

Aliman Syahuri Zein

\section{Kajian Teoritik}

Berbicara tentang kemiskinan, maka yang muncul bukanlah permasalahan tentang kesadaran orang kaya akan pentingnya harta zakat. Akan tetapi, disebabkan oleh krisis mental orang miskin yang malas untuk bangkit yang telah melanda sebagian besar masyarakat Muslim saat ini. Jika kita mau kembali pada Al-Qur'an, sebenarnya Allah Swt telah menjelaskan pada ummat Islam bahwa kemiskinan tidak datang dari sang pencipta akan tetapi kemiskinan datang dari manusia itu sendiri. Dalam hal ini, penyataan Susan George menarik untuk disimak bahwa penyebab utama kemiskinan adalah ketimpangan sosial-ekonomi karena adanya sekelompok kecil orang-orang yang hidup mewah di atas penderitaan orang banyak, dan bukannya diakibatkan oleh semata- mata kelebihan jumlah penduduk. Di antara gambaran Al-Qur'an yang berkaitan dengan sifat manusia yang menyebabkan kemiskinan misalnya. Pertama, QS. An-Nahl ayat 112 yang menceritakan suatu negeri yang diberi rasa lapar dan ketakutan sebagai balasan dari sifat "kufur nikmat" atau tidak mensyukuri nikmat Allah SWT. Kedua, QS. Al-Ma'arij ayat 19-21 yang menjelaskan tentang mudahnya manusia putus asa dan lemahnya etos kerja. Arti dari ayat tersebut adalah "dan Allah telah membuat suatu perumpamaan (dengan) sebuah negeri yang dahulunya aman lagi tenteram, rezekinya datang kepadanya melimpah ruah dari segenap tempat, tetapi (penduduk)nya mengingkari nikmat-nikmat Allah; karena itu Allah merasakan kepada mereka pakaian kelaparan dan ketakutan, disebabkan apa yang selalu mereka perbuat”. (QS. An-Nahl [16]:112).

Zakat merupakan sistem ekonomi ummat Islam. Dengan pengelolaan yang baik pada akhirnya zakat akan mampu membangun pertumbuhan ekonomi sekaligus pemerataan pendapatan. Selain itu dalam zakat mengandung nilai-nilai sosial, politik, moral dan agama sekaligus. Hal ini dapat dilihat dari segi manfaat yang akan dirasakan baik oleh pemberi maupun penerima zakat. Di sinilah letak perbedaan antara sistem kapitalisme dengan zakat. Kapitalisme menganjurkan manusia untuk menumpuk-numpuk harta sebanyak mungkin tanpa memperdulikan orang lain. Sedangkan zakat lebih mengedapankan maslahat bersama daripada individu. Untuk itulah pentingnya pemerataan kekayaan agar tidak terjadi ketidakseimbangan kekayaan atau 
kesenjangan sosial. Dengan dijadikannya zakat sebagai instrument pemerataan kekayaan maka harta selanjutnya harus didistribusikan kepada pihak lain, yaitu orang-orang telah ditentukan (Fakir, Miskin, Amil, Mu`alaf, Hamba Sahaya, Gharimin, Fii Sabilillah, Ibnu Sabil) sehingga hal tersebut perlu diatur dalam sebuah mekanisme redistribusi yang jelas.

Apabila fungsi zakat sebagai instrument penyaluran kekayaan ini dijalankan secara maksimal dengan pembagian yang merata maka persoalan kemiskinan dan kesenjangan sosial dapat diperkecil. Akan tetapi itu merupakan harapan yang masih jauh dari kenyataan. Yang perlu dioptimalkan terlbih dulu adalah menangulangi kemiskinan dengan cara pendekatan yang komprehensif, yaitu upaya perubahan mental dari dalam diri orang-orang miskin serta memberikan pemahaman kepada orang-orang kaya akan kesadaran mengeluarkan zakat. Tentunya harus dibarengi juga dengan manajemen pemerataan zakat secara profesional oleh pemerintah. Dan jika tiga unsur tersebut bisa berhasil barulah kesejahteraan sosial ummat akan tercipta. Dalam konteks Islam apabila sistem zakat dapat dijalankan secara baik dan benar, maka tidak ada orang atau kelompok masyarakat yang menderita. Sementara sebagian yang lain hidup berkemakmuran dan kemewahan. Semangat yang ingin ditanamk kepada seluruh manusia melalui ajaran zakat, yaitu semangat untuk berusaha dan memperbaiki kehidupan ekonomi masyarakat (ummat). Untuk itu, pendayagunaan zakat perlu diarahkan dan difokuskan sebagai salah satu instrumen dalam pemberdayaan ekonomi dan kehidupan masyarakat (ummat). Perkembangan Zakat Dari masa kemasa Zakat merupakan guru perekonomian Islam yang sejak lama telah disyariatkan dan dikembangkan sejak zaman Rasulullah Saw.

Dalam hal ini zakat berfungsi sebagai instrumen yang mengatur aliran redistribusi pendapatan dan kekayaan tersebut. Di sinilah tugas pemerintah untuk mengatur penyaluran harta zakat semaksimal mungkin. Apabila fungsi zakat sebagai instrument penyaluran kekayaan ini dijalankan secara maksimal dengan pembagian yang merata maka persoalan kemiskinan dan kesenjangan sosial dapat diperkecil. Akan tetapi itu merupakan harapan yang masih jauh dari kenyataan. Yang perlu dioptimalkan terlbih dulu adalah menangulangi kemiskinan dengan cara pendekatan yang komprehensif, yaitu upaya 


\section{Strategi Pemberdayaan Ekonomi Mustahiq Melalui \\ Pendistribusian Zakat Produktif}

Aliman Syahuri Zein

perubahan mental dari dalam diri orang-orang miskin serta memberikan pemahaman kepada orang-orang kaya akan kesadaran mengeluarkan zakat. Tentunya harus dibarengi juga dengan manajemen pemerataan zakat secara profesional oleh pemerintah. Dan jika tiga unsur tersebut bisa berhasil barulah kesejahteraan sosial ummat akan tercipta. Dalam konteks Islam apabila sistem zakat dapat dijalankan secara baik dan benar, maka tidak ada orang atau kelompok masyarakat yang menderita. Sementara sebagian yang lain hidup berkemakmuran dan kemewahan. Semangat yang ingin ditanamk kepada seluruh manusia melalui ajaran zakat, yaitu semangat untuk berusaha dan memperbaiki kehidupan ekonomi masyarakat (ummat). Untuk itu, pendayagunaan zakat perlu diarahkan dan difokuskan sebagai salah satu instrumen dalam pemberdayaan ekonomi dan kehidupan masyarakat (ummat). Perkembangan Zakat Dari masa kemasa Zakat merupakan guru perekonomian Islam yang sejak lama telah disyariatkan dan dikembangkan sejak zaman Rasulullah Saw.

\section{Manajemen Strategi}

Berbicara tentang strategi selalu dikaitkan dengan manajemen, karena manajemen stategi merupakan serangkaian keputusan atau tindakan mendasar yang dilakukan oleh pihak manajemen dan perlu diimplementasikan oleh unsur-unsur organisasi/lembaga untuk mencapai tujuan yang telah ditetapkan. Namun definisi yang diberikan oleh beberapa ahli terhadap manajemen strategi antara lain; Glueck dan Jauch mendefenisikan "Sejumlah keputusan dan tindakan yang mengarah pada penyusunan suatu strategi atau sejumlah strategi yang efektif untuk membantu mencapai sasaran organisasi”.

Sedangkan Hunger J. David Hunger \& Thomas L. Wheelen dalam buku Julianto Agung mendefenisikan "Serangkaian keputusan dan tindakan manajerial yang menentukan kinerja perusahaan dalam jangka panjang”. Defenisi lain mengatakan bahwa manajemen strategis berfokus dalam mengintegrasikan manajemen, pemasaran, keuangan/akuntansi, produksi/operasi, penelitian dan pengembangan, serta sistem informasi komputer untuk mencapai keberhasilan organisasi. Jika dilihat dari konteks Islam, manajemen dinyatakan sebagai rangkaian proses yang mencakup 
tahapan formulasi, implementasi, dan evaluasi keputusan-keputusan strategis organisasi yang memungkinkan pencapaian tujuannya dimasa mendatang. Adapun tolak ukur yang digunakan adalah adanya perbedaan antara aktivitas yang halal dan haram dalam sebuah proses.

Beberapa manfaat yang dapat diperoleh memalui manajemen strategi antara lain: (a) dapat dilakukan identifikasi, penentuan prioritas, dan eksploitasi peluang, (b) Merepresentasikan kerangka kerja untuk aktivitas kontrol dan koordinasi yang lebih baik, (c) Memungkinkan alokasi waktu dan sumber daya yang lebih efektif untuk peluang yang telah terindentifikasi, (d) Memungkinkan alokasi sumber daya dan waktu yang lebih sedikit untuk mengoreksi keputusan yang salah atau tidak terencana, (e) Menciptakan kerangka kerja untuk komunikasi internal diantara staf. Adapun proses manajemen strategi dibagi menjadi empat tahap, yaitu: pengamatan lingkungan, perumusan strategi, implementasi strategi, evaluasi dan pengendalian.

\section{Strategi Pemberdayaan Ekonomi Masyarakat}

Istilah pemberdayaan berasal dari bahasa Inggris yaitu empowerment yaitu dari kata dasar power yang berarti kemampuan berbuat, mencapai, melakukan atau memungkinkan. Sedangkan awalan "em" berasal dari bahasa Latin dan Yunani, yang berarti di dalamnya. Dengan demikian pemberdayaan dapat berarti kekuatan dalam diri manusia, suatu sumber kreatifitas. Menurut bahasa, pemberdayaan berasal dari kata daya yang berarti tenaga atau kekuatan. Jadi, pemberdayaan adalah suatu upaya untuk membangun daya masyarakat dengan mendorong, memotivasi, dan membangkitkan kesadaran akan potensi yang dimiliki serta berupaya untuk mengembangkan. Konsep pemberdayaan mempunyai dua makna, yakni mengembangkan dan memandirikan, menswadayakan masyarakat lapisan bawah terhadap penekanan sektor kehidupan. Sedangkan makna lainnya adalah melindungi, membela dan berpihak kepada yang lemah.

Pemberdayaan masyarakat merupakan suatu upaya yang dilakukan untuk meningkatkan kemampuan masyarakat dalam mewujudkan kemandirian dan melepaskan diri dari belenggu kemiskinan serta keterbelakangan. Sedangkan 


\section{Strategi Pemberdayaan Ekonomi Mustahiq Melalui \\ Pendistribusian Zakat Produktif}

Aliman Syahuri Zein

pemberdayaan di bidang ekonomi merupakan upaya yang dilakukan untuk membangun masyarakat dengan mendorong, memotivasi, dan membangkitkan kesadaran akan potensi ekonomi yang dimilikinya serta berupaya untuk mengembangkannya. Keberdayaan masyarakat adalah unsur dasar yang memungkinkan suatu masyarakat bertahan.

Dalam pengertian lain, yaitu mengembangkan diri dan mencapai kemajuan. Program-program masyarakat yang disiapkan harus memenuhi kebutuhan masyarakat. Perencanaan-perencanaan yang menyusun programprogram atau kegiatan usahanya di suatu daerah harus melakukan analisis kebutuhan masyarakat. Dalam melakukan analisis kebutuhan masyarakat harus benar-benar dapat memenuhi kebutuhan (need analisis), dan bukan sekedar membuat daftar keinginan (list of wants) yang bersifat sementara.

Analisis kebutuhan harus dilakukan secara cermat agar dapat menggali kebutuhan-kebutuhan yang sesungguhnya dibutuhkan oleh masyarakat banyak, bukan merupakan keinginan beberapa orang saja, apakah tokoh masyarakat, atau kepala desa yang mempunyai kewenangan menentukan keputusan. Dalam pembangunan masyarakat (community development) mengandung upaya untuk meningkatkan partisipasi dan rasa memiliki (participating and belonging together) terhadap program yang dilaksanakan, dan harus mengandung unsur pemberdayaan masyarakat.

Menurut Sumodiningrat, pemberdayaan masyarakat harus dilakukan melalui 3 (tiga) jalur, yaitu; Menciptakan iklim yang memungkinkan potensi masyarakat berkembang (Enabling); Menguatkan potensi dan daya yang dimiliki masyarakat (Empowering); dan Memberikan perlindungan (Protecting).

Disamping itu juga dalam konsep pemberdayaan masyarakat memiliki dua makna yaitu mengembangkan dan memandirikan, menswadayakan masyarakat dari lapisan bawah sehingga dapat menekan sektor kehidupan. Makna lainnya konsep pemberdayaan itu yaitu melindungi, membela dan berpihak kepada yang lemah untuk mencegah terjadinya eksploitasi terhadap yang lemah. 
Pemberdayaan menuntut adanya perubahan banyak aspek dalam masyarakat. Pemberdayaan melibatkan apa yang disebut dengan memberikan kebebasan kepada setiap orang untuk dapat menggunakan kemampuan yang ada dalam dirinya. Di samping itu mereka juga harus bertindak sebagai navigator dalam perjalanan menuju pemberdayaan. Pemberdayaan secara pasti dapat diwujudkan, tetapi perjalanan tersebut tidaklah berlaku bagi mereka yang tidak semangat. Pemberdayaan mendasarkan pada pengakuan yang eksplisit bahwa orang-orang dalam masyarakat memiliki kemampuan yang mencakup pengalaman, pengetahuan, serta motivasi internal mereka.

Dengan demikian pemberdayaan masyarakat adalah sebagai suatu pembinaan atau pemberdayaan yang dikembangkan untuk merubah dan sekaligus meningkatkan perekonomian dan taraf hidup masyarakat, jadi dalam hal ini masyarakat adalah sarana dan tujuan dalam pemberdayaan. Pemberdayaan masyarakat mempunyai arti memandirikan masyarakat tersebut, sehingga masyarakat dalam hal ini adalah orang-orang yang berhak menerima zakat (mustahiq) tidak selamanya tergantung kepada orang-orang yang wajib mengeluarkan zakat (muzakki).

Pemberdayaan merupakan penyaluran dana yang disertai target yang tidak dapat dengan mudah atau dalam waktu yang singkat dapat terealisasi. Karena itu, penyaluran dana tersebut harus disertai dengan pemahaman yang utuh terhadap permasalahan yang ada pada masyarakat sebagai penerima dana. Apabila permasalahannya adalah kemiskinan, harus diketahui penyebab kemiskinan tersebut, sehingga dapat mencari solusi yang tepat demi tercapainya target yang telah direncanakan. Dalam pemberdayaan masyarakat melalui beberapa saluran mempunyai tujuan antara lain adalah pengentasan kemiskinan, perbaikan distribusi pendapatan, penciptaan lapangan kerja, dan jaring pengaman sosial.

\section{Pemberdayaan Melalui Distribusi Zakat}

Distribusi berasal dari bahasa Inggris yaitu distribute yang berarti pembagian atau penyaluran. secara istilah terminologi distribusi adalah penyaluran (pembagian) kepada orang banyak atau beberapa tempat. Pengertian lain mendefinisikan bahwa distribusi adalah sebuah upaya 


\section{Strategi Pemberdayaan Ekonomi Mustahiq Melalui \\ Pendistribusian Zakat Produktif}

Aliman Syahuri Zein

penyaluran barang keperluan sehari-hari oleh pemerintah kepada pegawai negeri, penduduk, dan sebagainya. Distribusi artinya proses yang menunjukkan bagaimana penyaluran barang dari produsen sampai ke tangan masyarakat konsumen. Distribusi merupakan kegiatan ekonomi yang menjembatani kegiatan produksi dan konsumsi. Melalui distribusi barang dan jasa akan sampai ke tangan konsumen.

Menurut Philip Kotler distribusi adalah serangkaian organisasi yang saling tergantung yang terlibat dalam proses untuk menjadikan produk atau jasa yang siap untuk digunakan atau dikonsumsi. Dalam hal ini distribusi dapat diartikan sebagai kegiatan (membagikan, mengirimkan) kepada orang atau kebeberapa tempat. Secara garis besar, pendistribusian dapat diartikan sebagai kegiatan pemasaran yang berusaha memperlancar dan mempermudah penyampaian barang dan jasa dari produsen kepada konsumen, sehingga penggunaannya sesuai dengan yang diperlukan (jenis, jumlah, harga, dan saat dibutuhkan). Dengan kata lain distribusi merupakan aktifitas pemasaran yang mampu menciptakan nilai tambah produk melalui fungsi-fungsi pemasaran yang dapat merealisasikan kegunaan atau fasilitas bentuk, tempat dan kepemilikan dan memperlancar arus saluran pemasaran (marketing chanel flow) secara fisik dan non fisik.

\section{Metode Penelitian}

Penelitian ini merupakan jenis penelitian kualitatif dengan metode studi kasus yang bertujuan untuk menemukan strategi pemberdayaan yang lebih efektif dan efisien. Data penelitian yang dibutuhkan mencakup data tentang jumlah mustahiq, pelaksanaan pemberdayaan ekonomi mustahiq, rekomendasi dari para mustahiq dan pengelola Baznas kabupaten Mandailing Natal. Populasi dalam penelitian ini adalah seluruh mustahiq yang terdaftar atau berada di lingkup wilayah operasi Baznas kabupaten Mandailing Natal. Disamping itu, juga seluruh pegawai Baznas yang relevan untuk memberikan informasi.

Teknik pengumpulan data yang digunakan melalui teknik wawancara secara mendalam dan diskusi dalam bentuk FGD, baik dengan para mustahiq maupun dengan pengelola Baznas. Teknik wawancara digunakan untuk mengevaluasi 
atau mereview strategi pemberdayaan ekonomi yang tepat bagi mustahiq. Sehingga diperoleh saran atau rekomendasi dari mustahiq guna menyempurnakan model pemberdayaan tersebut. Data yang telah terkumpul selanjutnya akan dianalisis. Analisis data diarahkan pada kegiatan sosialisasi strategi pemberdayaan ekonomi yang tepat bagi mustahiq. Sosialisasi startegi tersebut dilakukan melalui kegiatan diskusi (FGD) secara mendalam.

Tahapan-tahapan penelitian terdiri dari: (1). Tahap Persiapan, dimana peneliti membuat pedoman wawancara yang disusun berdasarkan permasalahan yang dihadapi subjek. Pedoman wawancara ini berisi pertanyaan-pertanyaan mendasar yang nantinya akan berkembang dalam wawancara. Pada tahap persiapan, peneliti akan membuat pedoman observasi yang disusun berdasarkan hasil observasi terhadap perilaku subjek selama wawancara dan observasi terhadap lingkungan, serta pengaruhnya terhadap perilaku subjek dan pencatatan langsung yang dilakukan pada saat peneliti melakukan observasi. Namun jika tidak memungkinkan, peneliti akan mencatatnya setelah wawancara berakhir. (2) Tahap pelaksanaan penelitian, pada tahap ini peneliti akan membuat kesepakatan dengan subjek tentang waktu dan tempat untuk melakukan wawancara berdasarkan pedoman yang dibuat. Setelah wawancara dilakukan, peneliti memindahakan hasil rekaman berdasarkan wawancara dalam bentuk tertulis. Selanjutnya peneliti melakukan analisis data dan interprestasi data sesuai dengan langkah-langkah yang telah ditentukan. kemudian, peneliti membuat kesimpulan dan saran untuk penelitian selanjutnya.

Dalam suatu penelitian kualitatif, terdapat empat jenis keabsahan yang diperlukan yaitu: (1) Keabsahan Konstruk (Construct validity): (Triangulasi data, Triangulasi Pengamat, Triangulasi Teori, dan Triangulasi metode), (2) Keabsahan Internal (Internal validity), (3) Keabsahan Eksternal (Eksternal validity), dan (4) Keajegan (Reabilitas). Sementara itu, beberapa tahapan yang dilakukan dalam analisa data meliputi: (1) Mengorganisasikan Data, (2) Pengelompokan berdasarkan Kategori, Tema dan pola jawaban, (3) Menguji Asumsi atau Permasalahan yang ada terhadap Data, (4) Mencari alternatif Penjelasan bagi data, dan (5) Menulis Hasil Penelitian. 


\section{Strategi Pemberdayaan Ekonomi Mustahiq Melalui \\ Pendistribusian Zakat Produktif}

Aliman Syahuri Zein

\section{Hasil dan Pembahasan}

Sejauh ini peneliti telah melakukan penelitian kelapangan. Penelitian yang dimaksud dalam hal ini dilakukan melalui proses observasi dan wawancara. Observasi langsung peneliti lakukan ke tempat usaha nasabah. Meskipun untuk saat ini baru ada 2 usaha nasabah yang berhasil dikunjungi. Sedangkan untuk wawancara, telah dilakukan baik dengan pihak BAZNAS selaku pengumpul dan pendistribusi dana zakat serta pihak mustahiq selaku pengelola dana zakat. Beberapa temuan penelitian yang telah diperoleh, baik melalui hasil wawancara maupun hasil observasi adalah sebagai berikut: Pertama, baznas Kabupaten Mandailing Natal telah lama ada, hanya saja belum beroperasi dengan optimal. Hal ini dikarenakan pada waktu itu Baznas bukanlah sebuah lembaga yang independen, melainkan berada di bawah kendali Pemerintah daerah. Oleh karena itu, berbagai kebijakan yang dilakukan oleh Baznas tentunya harus sejalan dengan kebijakan Pemerintah daerah. Struktur kepengurusan yang ada di Baznas saat ini merupakan struktur yang baru terbentuk, pada tahun 2018. Dengan demikian kepengurusan ini mulai bekerja sejak tahun 2018 yang lalu. Oleh karena itu, untuk sebuah lembaga jelas masih tergolong sangat muda, apalagi jika ingin memfokuskan pada tugas pokoknya dalam menghimpun dan menyalur dana zakat. Meskipun tergolong masih baru, namun sejak Desember 2018 hingga Mei 2019, Baznas kabupaten Mandailing Natal telah mampu mendistribusikan dana zakat produktif sebanyak 165.000.0oo rupiah. Kedua, jumlah zakat produktif didistribusikan kepada 32 orang meliputi seluruh wilayah kabupaten Mandailing Natal. Besarnya zakat yang didistribusikan bervariasi, yaitu disesuaikan dengan besarnya jenis usaha. Variasi dana yang didistribusikan tersebut mulai dari 2.500.000 rupiah hingga 10.000.000 rupiah. Ketiga, secara umum mekanisme yang dilakukan dalam pendistribusian zakat produktif ini adalah dengan menganalisa permohonan pinjaman dana zakat produktif yang diajukan oleh calom mustahiq. Adapun untuk system pengembalian yang ditetapkan disesuaikan dengan jangka waktu pinjaman, dengan menggunakan akad rahn. Artinya mustahiq wajib mengembalikan sejumlah dana zakat yang dipinjam kepada Baznas sesuai dengan jangka waktu yang disepakati tanpa dibebankan bunga. Pengembalian pinjaman tidak ditetapkan tentang jumlah dan waktunya. Artinya apakah bulanan atau 
bagaiamana. Bagi pihak Baznas yang terpenting dana zakat produktif yang dipakai mustahiq harus dilunasi dalam jang waktu satu tahun. Keempat, sebelum memberikan dana zakat, pihak Baznas tidak terjun langsung ke lapangan melihat usaha yang dijadikan dasar hokum peminjaman dana oleh mustahiq. Sehingga dasar hukum yang dijadikan sebagai patokan hanyalah berkas-berkas mustahiq. Sampai saat ini Pihak Baznas belum pernah melakukan pendampingan serta usaha controlling terhadap usaha mustahiq. Apakah usaha mustahiq berjalan, atau bahkan dana zakat disalahgunakan. Kelima, Jumlah pengajuan diri sebagai calon mustahiq terus meningkat dari masayarakat kabupaten Mandailing Natal. Sehingga tidak semua pinjaman yang diajukan mustahiq dapat direalisasikan oleh pihak Baznas.

Pengelolaan zakat produktif sebenarnya dapat dilakukan dengan tiga pola yaitu pola program, kemitraan dan pola otonom. Pola pertama, zakat produktif sebagai program dilakukan dapat dilakukan sendiri oleh pihak Baznas. Artinya Baznas dapat membentuk unit atau lembaga tersendiri untuk mengelola zakat produktif. Baznas dapat menunjukkan pengelola, melakukan seleksi calon mustahik, menyalurkan dana, melakukan pendampingan dan manajemen risiko. Baznas bertanggungjawab terhadap sukses dan gagalnya program. Pola kedua, baitul mal dapat bermitra dengan lembaga profesional pengelola dana seperti BPRS, BMT dan Koperasi Simpan Pinjam Syariah. Dalam hal ini Baznas dapat menyeleksi proposal dari mitra, menempatkan dana zakat pada mitra, melakukan monitoring dan meminta pertangungjawaban pengelolaan dana. Baznas berfungsi sebagai badan penyandang dana atau funding. Ketiga, Baznas membentuk badan otonom atau badan hukum untuk mengelola zakat produktif. Badan hukum dapat berbentuk koperasi syariah atau Perseroan Terbatas. Jadi Baznas adalah inisiator dan pemilik badan hukum tersebut. Dalam hal ini tanggungjawab pengelolaan dana zakat produktif dilakukan badan hukum profesional, sementara Baznas adalah sebagai investor. Upaya menemukan pola ideal pengelolaan zakat produktif terus berkembang di berbagai wilayah. Hal ini terjadi karena keyakinan bahwa zakat produktif dapat mengurangi angka kemiskinan. Zakat harus menjadi bagian dari solusi dalam penanggulangan kemiskinan, mengurangi kesenjangan ekokonomi dan memberi akses yang luas terhadap kaum miskin dalam mendapatkan modal 


\section{Strategi Pemberdayaan Ekonomi Mustahiq Melalui \\ Pendistribusian Zakat Produktif}

Aliman Syahuri Zein

usaha. keempat, berkembang isu pengelolaan zakat produktif dapat dilakukan dalam bentuk community development atau pengembangan masyarakat. Pola ini, Baitul Mal menetapkan satu lokasi atau komunitas, selanjutnya dilakukan analisis kebutuhan, pemetaan potensi, pendampingan dan mengorganisirnya menjadi kekuatan bersama untuk keluar dari kemiskinan. Pengembangan masyarakat dilakukan dengan prioritas kegiatan kesehatan, pendidikan, pemberdayaan ekonomi dan pendampingan ibadah.

Selain sedang menemukan pola ideal penyaluran zakat produktif, Baznas juga dihadapkan pada kenyataan belum lengkapnya regulasi. Ragulasi ini menjadi hal penting, karena pengelolaan zakat dilakukan oleh negara/pemerintah. Regulasi yang diperlukan adalah pengaturan zakat produktif dan regulasi pelaksana lainnya. Termasuk melangkapi petunjuk operasional dan Strandar Operasional Prosedur (SOP). Beberapa hal yang diatur terkait zakat produktif misalnya pengertian definisi zakat produktif, status modal usaha, perlakuan terhadap dana macet serta penghapusan. Perlu diperjelas penggunaan dana operasional, pendampingan dan penatausahaan zakat produktif dalam konteks zakat sebagai PAD (Pendapatan Asli Daerah), yang merupakan fleksibelitas pengelolaan syariah zakat. Baznas Kabupaten Mandailing Natal sejatinya merumuskan zakat produktif sebagai solusi kemiskinan, menjadikannya sebagai program unggulan dan menyepakati pola pengelolaan yang digunakan. Apabila Zakat Community Development (ZCD) yang menjadi pilihan sebagai program nasional, maka zakat produktif dapat diintegarisikan dalam program pemberdayaan ekonomi komunitas. Lebih praktis lagi dijadikan bagian dari pemberdayaan ekonomi masyarakat. Oleh karena itu, manajemen zakat produktif harus secepatnya dilakukan penataan sehingga tidak menyisakan permasalahan keuangan di kemudian hari. Penataan dapat dimulai dari pengaturan zakat produktif serta menetapkan pola pengelolaan apakah bersifat program, kemitraan atau berbadan hukum tersendiri.

Pemberian zakat kepada para mustahik secara konsumtif dan produktif perlu dilakukan sesuai kondisi mustahiq. Untuk mengetahui kondisi mustahiq, petugas amil zakat perlu memastikan kelayakan para mustahiq, apakah mereka dapat dikategorikan mustahiq produktif atau mustahiq konsumtif. Ini 
memerlukan analisis tersendiri oleh para amil zakat, sehingga zakat benarbenar sampai kepada orang-orang yang berhak menerimanya secara objektif. Penyaluran zakat dilihat dari bentuknya dapat dilakukan dalam dua hal yakni bentuk sesaat dan bentuk pemberdayaan. Pertama, penyaluran bentuk sesaat adalah penyaluran zakat hanya diberikan kepada seseorang atau satu kali atau sesaat saja. Dalam hal ini juga berarti bahwa penyaluran kepada mustahiq tidak disertai target terjadinya kemandirian ekonomi dalam diri mustahiq. Hal ini di karenakan mustahiq yang bersangkutan tidak mungkin mandiri lagi seperti pada diri orang tua yang sudah jompo, dan orang cacat. Kedua, penyaluran bentuk pemberdayaan merupakan penyaluran zakat yang disertai target merubah kondisi mustahiq menjadi kategori muzakki. Target ini adalah target besar yang tidak dapat dengan mudah atau dalam waktu yang singkat dapat terealisasi. Karena itu penyaluran zakat harus disertai dengan pemahaman yang utuh terhadap permasalahan yang ada pada penerima. Apabila permasalahannya adalah permasalahan kemiskinan harus diketahui penyebab kemiskinan tersebut, sehingga dapat mencari solusi yang tepat demi tercapainya target yang telah direncanakan.

Selama ini kegiatan pendayagunaan dana zakat yang dilakukan oleh BAZ dan LAZ yang mencakup kegiatan jangka panjang dan jangka pendek dibidang produksi, konsumsi maupun program sosial kemasyarakatan. Sementara itu, pendayagunaan dana zakat untuk tujuan usaha-usaha produktif tampaknya lebih dititik beratkan pada satu titik pusat pemberdayaan melalui sejumlah program seperti, pembinaan dan penyuluhan sosial ekonomi dan teknik usaha, bantuan beasiswa dan bea guru, pelatihan keterampilan, perawatan kesehatan dan pembiayaaan pengobatan, pembangunan sarana pendidikan, pembiayaan usaha produktif, menciptakan lapangan kerja melalui pengembangan usaha, Bantuan modal usaha kecil rumah tangga, pengembangan investasi pada proyek tertentu.

\section{Kesimpulan}

Berdasarkan hasil penelitian, maka dapat disimpulkan sebagai berikut: Konsep pengelolan zakat produktif yang dilakukan Baznas Kabupaten Mandailing Natal masih tergolong tradisional. Artinya baru hanya melibatkan 


\section{Strategi Pemberdayaan Ekonomi Mustahiq Melalui \\ Pendistribusian Zakat Produktif}

Aliman Syahuri Zein

pihak Baznas dan mustahiq. Dimana mustahiq dating ke Baznas dengan mengajukan permohonan dana zakat produktif. Setelah berkas-berkas pengajuan diserahkan, maka berkas-berkas tersebut akan diverivikasi untuk dapat dilakukan penetapan sebagai mustahiq zakat produktif. Konsep pemberdayaan ekonomi mustahiq yang dilakukan Baznas Kabupaten Mandailing Natal hanya sebatas controlling usaha. Controlling ini dilakukan secara tidak langsung, biasanya melalui telepon. Kegiatan controlling ini dilakukan dengan tidak terjadwal. Kendala yang dihadapi Baznas Mandailing Natal dalam pemberdayaan ekonomi mustahiq antara lain; SDM (petugas) Baznas yang terbatas, tempat tinggal mustahiq jauh, sehingga sulit untuk dijangkau, mustahiq menyalahgunakan dana zakat yang diterima, sehingga tidak sesuai dengan yang diajukan. Strategi yang tepat dilakukan oleh Baznas Mandailing Natal untuk pemberdayaan ekonomi mustahiq ke depan, antara lain: a) merubah pola distribusi zakat produktif dari tradisional menjadi lebih modern, b)menerapkan prinsip $5 \mathrm{C}$ untuk menilai karakter calon mustahiq, c)melakukan pendampingan secara maksimal terhadap usaha mustahiq.

\section{Daftar Referensi}

Anwar, Achmad Syaiful Hidayat. Model Pemberdayaan Ekonomi Mustahiq Melalui Zakat, dalam Jurnal Jeam, Volume XV, Edisi April, Tahun 2016.

Anwar, Ahmad Thoharul. Zakat Produktif Untuk Pemberdayaan Ekonomi Umat, Jurnal Zakat dan Wakaf, Volume, 5, Nomor, 1, Edisi Juni, Tahun 2018.

Bantanie, Syafeci., Zakat, Infak, dan Sedekah. Bandung: Salamadani, 2011

Hafidhuddin, Didin., Zakat Dalam Perekonomian Modern. Jakarta: Gema Insani. 2002.

Hafidhuddin, Didin.,.. Panduan Praktis tentang Zakat, Infak, Sedekah. Jakarta: Gema Insani. 1998.

Helmy, Masdar., Memahami Zakat dan Cara Menghitungnya. Bandung: Al Ma"arif. 2001.

Hunger, J. David \& Wheelen, L. Thomas. Manajemen Strategis, terj. Julianto Agung. Yogyakarta: Andi, 2009. 
Iriantara, Yosal., Manajemen Strategis Public Relations. Jakarta: Ghalia Indonesia. 2004

Ismail Yusanto, Muhammad dan Karebet Widjajakusuma, Muhammad.

Manajemen Strategis: Perspektif Syari’ah. Jakarta: Khairul Bayan. 2003.

Jauch, Lawrence R. dan F. Glueck, William. Manajemen Strategis dan Kebijakan Perusahaan. terj. Murad dan Henry Sitanggang. Jakarta: Erlangga, 1998.

Maghfiroh, Siti. Model Manajemen Strategis Pemberdayaan Ekonomi Umat Melalui Zakat,Infak, Sedekah (Studi Kasus pada LAZIS Qaryah Thayyibah Purwokerto), dalam jurnal Economic: Jurnal Ekonomi dan Hukum Islam, Volume 5, Nomor 2, tahun 2015.

Mubasiruna, Distribusi Zakat Dan Pemberdayaan Ekonomi Umat, dalam jurnal Inferensi: Jurnal Penelitian Sosial Keagamaan. Volume 7, Nomor. 2, tahun 2013 .

Muhammad Hasbi Ash Shiddieqy, Teungku., Pedoman Zakat. Semarang: Pustaka Rizki Putra, 2002.

Nizar, Muhammad. Model Pemberdayaan Ekonomi Masyarakat Melalui Pengelolaan Zakat, Infaq Dan Shadaqah (ZIS) Di Masjid Besar Syarif Hidayatullah Karangploso Malang, dalam jurnal Malia, Volume 8, Nomor 1, Edisi Desember, tahun 2016.

Pearce II, John A. dan Robinson, Jr Richard B., Manajemen-Strategis, Formulasi, Implementasi dan Pengendalian. Jakarta: Salemba Empat, 2008.

R. David, Fred., Strategic Management: Concepts and Cases, Terj. Ichsan Setyo Budi. Jakarta: Salemba Empat, 2006.

Rahardjo, M. Dawam. Islam dan Transformasi Sosial-Ekonomi. Yogyakarta: Pustaka Pelajar. 1999.

Rivai, Veithzal dan Arviyan Arifin, Islamic Banking. Jakarta: Bumi Aksara, 2010.

Siagian, Sondang P. Manajemen Sumber Daya Manusia. Jakarta: Bumi Aksara. 1999.

Syaiful dan Suwarno, Kajian Pendayagunaan Zakat Produktif Sebagai Alat Pemberdayaan Ekonomi Masyarakat (Mustahiq) Pada Lazismu Pdm Di Kabupaten Gresik, dalam jurnal Benefit: Managemen dan Bisnis, Volume 19, Nomor 2, Edisi Desember, Tahun 2015 